\title{
Municipal Solid Waste Management and Potential Revenue from Recycling in Malaysia
}

\author{
Anwar Johari ${ }^{1}$, Habib Alkali ${ }^{1}$, Haslenda Hashim², Saeed I. Ahmed ${ }^{1} \&$ Ramli Mat $^{1}$ \\ ${ }^{1}$ Faculty of Chemical Engineering, Universiti Teknologi Malaysia, 81310 UTM Skudai, Johor Bahru, Malaysia \\ ${ }^{2}$ Process Systems Engineering (PROSPECT), Faculty of Chemical Engineering, Universiti Teknologi Malaysia, \\ Johor Bahru, Malaysia \\ Correspondence: Habib Alkali, Faculty of Chemical Engineering, Universiti Teknologi Malaysia, 81310 UTM \\ Skudai, Johor Bahru, Malaysia. Tel: 60-143-992-116. E-mail: habalkali@yahoo.com
}

Received: April 2, 2014 Accepted: April 17, $2014 \quad$ Online Published: June 25, 2014

doi:10.5539/mas.v8n4p37 URL: http://dx.doi.org/10.5539/mas.v8n4p37

\begin{abstract}
Municipal Solid Wastes (MSW) issues have become talk of the day worldwide because of the current and the future threats it has to both life and the environment. Malaysia, like other developing nations, has been facing serious problems in recent years in terms of MSW and its management due to the nation's rapid economic growth. The objective of this paper is to review and present the current state of MSW and its management in Malaysia and to estimate the economic potentials of some recyclables as well. MSW generation in Malaysia has increased significantly in recent years, ranging between $0.5-2.5 \mathrm{~kg}$ per capita per day (or a total of 25000 30000 tons per day). Generally, the waste contains high amount of organics, moisture content and bulk density. More than $70 \%$ of the generated wastes are collected using both curbside and communal centers with a collection frequency varying from daily to every two days. In addition, both compactor trucks and open lorry trucks are used. Landfilling is the main disposal method practiced; about $90-95 \%$ of the collected wastes is still disposed in landfills, with a recycling rate of $5-10 \%$ despite the fact that $70-80 \%$ of the waste is recyclable. Estimation of the amount of recyclables and their revenue generation potential shows an impressive result. Recycling and composting of the municipal solid waste is therefore recommended.
\end{abstract}

Keywords: economics, landfilling, Malaysia, management, municipal solid waste, recyclables

\section{Introduction}

Malaysia has over the years been experiencing rapid growth in population, urbanization and industrialization. Currently, the population is about 28.5 million and more than $70 \%$ of this was reported to be living in the urban areas. This rapid development has resulted in the generation of greater amount of municipal solid wastes (Badgie et al., 2012; Fauziah \& Agamuthu, 2012). In a general term, it was reported that the greater the economic prosperity of any nation the higher the rate of urbanization and consequently the greater the amount of solid waste produced and Malaysia is one of such nations (Kathirvale et al., 2003; Uiterkamp et al., 2011). Owing to the rapid increase, the search for and the provision of an efficient management method of these wastes has become a serious concern (Al Ansari, 2012).

Solid wastes are the materials that have become of no or less value to the real owner and therefore planned to be thrown away. The material may not necessarily be valueless, but as long as the owner throws it away, it has become a waste. Municipal solid wastes (MSW) on the other hand, are the wastes produced in urban areas. In Malaysia, the Solid Waste and Public Cleansing Management Act 2007 defined solid waste as any scrap material or other unwanted surplus substance or rejected products that arise as a result of human activity, but excluding scheduled wastes, sewage and radioactive wastes (Agamuthu \& Dennis, 2011).

Solid waste management encompasses all the activities from generation to the final disposal and is defined as the control, generation, storage, collection, transfer and transportation, processing and disposal of solid waste consistent with the best practices of public health, economics and finance, engineering, administration, legal and environmental considerations. Like in other parts of the developing nations, its production in Malaysia has been seriously on the increase at an annual rate of $3-4 \%$ (Manaf et al., 2009). The daily amount of solid wastes produced in the recent has reached about 30,000 tons (Agamuthu \& Fauziah, 2011). Out of these amounts, about 
$70 \%$ was reported to be collected and about $95 \%$ (which is $75 \%$ of waste generated) of the collected wastes are disposed of in landfills with only about $5 \%$ being recycled (Agamuthu et al., 2009b). Many studies on solid waste management in Malaysia were carried out by different researchers with most reporting dumping and landfilling as the main disposal method (Lau, 2004; Sakawi, 2011; Tarmudi et al., 2012).

The main challenge facing Malaysia is how to effectively and sustainably manage this continuously increasing MSW. These challenges include inadequate collection, recycling or treatment and uncontrolled disposal of waste in ordinary dumps, leading to severe hazards and environmental pollutions (Agamuthu, 2001). For example, when rain falls it washes away some of these wastes and the leachates into water sources like rivers, hence subjecting the environment to more pollution risk (Pukkalanun et al., 2013). From these dumps also, greenhouse gases (GHG) are emitted into the atmosphere, contributing to climate change, which is another issue of serious concern. These situations among others make an MSW disposal practice to be considered as one of the sources of environmental degradation (Manaf et al., 2009; Fauziah et al., 2004; Ngoc \& Schnitzer, 2009). In fact, these are some of the reasons that prompted the federal government of Malaysia to take over the responsibilities which was earlier vested on the local authorities for managing these ever increasing waste quantities.

The Environmental Quality Act 1974 and the Local Government Act 1976 which was found to be inadequate were amended in order to improve the quality of the environment (Tarmudi et al., 2012). This resulted in the emergence of other solid waste management legislations such as the Action Plan for a Beautiful and Clean Malaysia (ABC) in 1988, the National Policy on the Environment (NPE) in 2002, the Environmental Quality (Scheduled Wastes) Regulations in 2005, the National Strategic Plan for Solid Waste Management (NSP) in 2005, the Master Plan on National Waste Minimization (MWM) in 2006, the National Solid Waste Management Policy in 2006, and the most current is the Solid Waste and Public Cleansing Management Act (SWPCM) in 2007.

In its effort to improve and ensure a quality service with respect to the management of solid waste, the government privatized the management of solid wastes in Malaysia. The four concessionaires which were awarded the contract include Alam Flora Sdn. Bhd., SW Environment Sdn. Bhd., E - Idaman Company, and Eastern Waste Management Sdn. Bhd. These concessionaires are the major firms responsible for waste management in Malaysia.

This paper is aimed at reviewing and presenting the current situation of municipal solid waste management practices in Malaysia. It discusses the policies and legislations available as well as generation, compositions and in general the way this rapidly increasing, heterogeneous and complex mixture of materials is managed. In addition, the amount of recyclables and the corresponding revenues that would be generated from these recyclables were estimated.

\section{Solid Waste and Public Cleansing Management Act 2007}

The Solid Waste and Public Cleansing Management Act (SWPCMA) is the currently existing SWM legislation in Malaysia. This act was reported to have been copied and applied from the best solid waste management practices of some developed countries such as Japan, Denmark, Switzerland, Germany and the United States of America. It mainly considered the management of public cleanliness/sanitation (Agamuthu \& Fauziah, 2011). The main strategies proposed for implementation under the Act includes source separation, efficient solid waste treatment, interim treatment and final disposal of solid waste particularly through landfills.

The gradual introduction of this Act started in September 2011. The responsibility for solid waste management and public cleansing was then transferred from the Local Authorities to the Federal Government. As a result, new federal institutions, including the Department of National Solid Waste Management and the Solid Waste Management and Public Cleansing Corporation were established. At least two clauses were incorporated which directly undertake 3R strategy. Clause 101 emphasized on Reduction, Reuse and Recycling of controlled solid waste while Clause 102 focused on system and deposit refund system. This act claims to bring solid waste management (SWM) in line with global state-of-the-art practices at no additional cost to the public. It includes regulation and enforcement tools as well as imposing higher responsibilities on the stakeholders. The act also enabled the privatization of SWM. Since its implementation commenced, the management of MSW was reported to have tremendously improved all over the country (Fauziah \& Agamuthu, 2012).

\section{Solid Waste Management History - Timeline}

In Malaysia, the management of solid wastes was carried out by the then district public health departments in the respective districts. In the seventies, the local authorities took over such responsibilities following the increasing awareness on the need for improved sanitation coupled with the corresponding increase in amount, volume and heterogeneity of the wastes (Fauziah \& Agamuthu, 2012). The local authorities were empowered by Section 72 
of the 1976 Local Government Act (Johari et al., 2012). As shown in Figure 1, the local authorities assisted by the state government were responsible for the management of solid waste up to the year 2011.

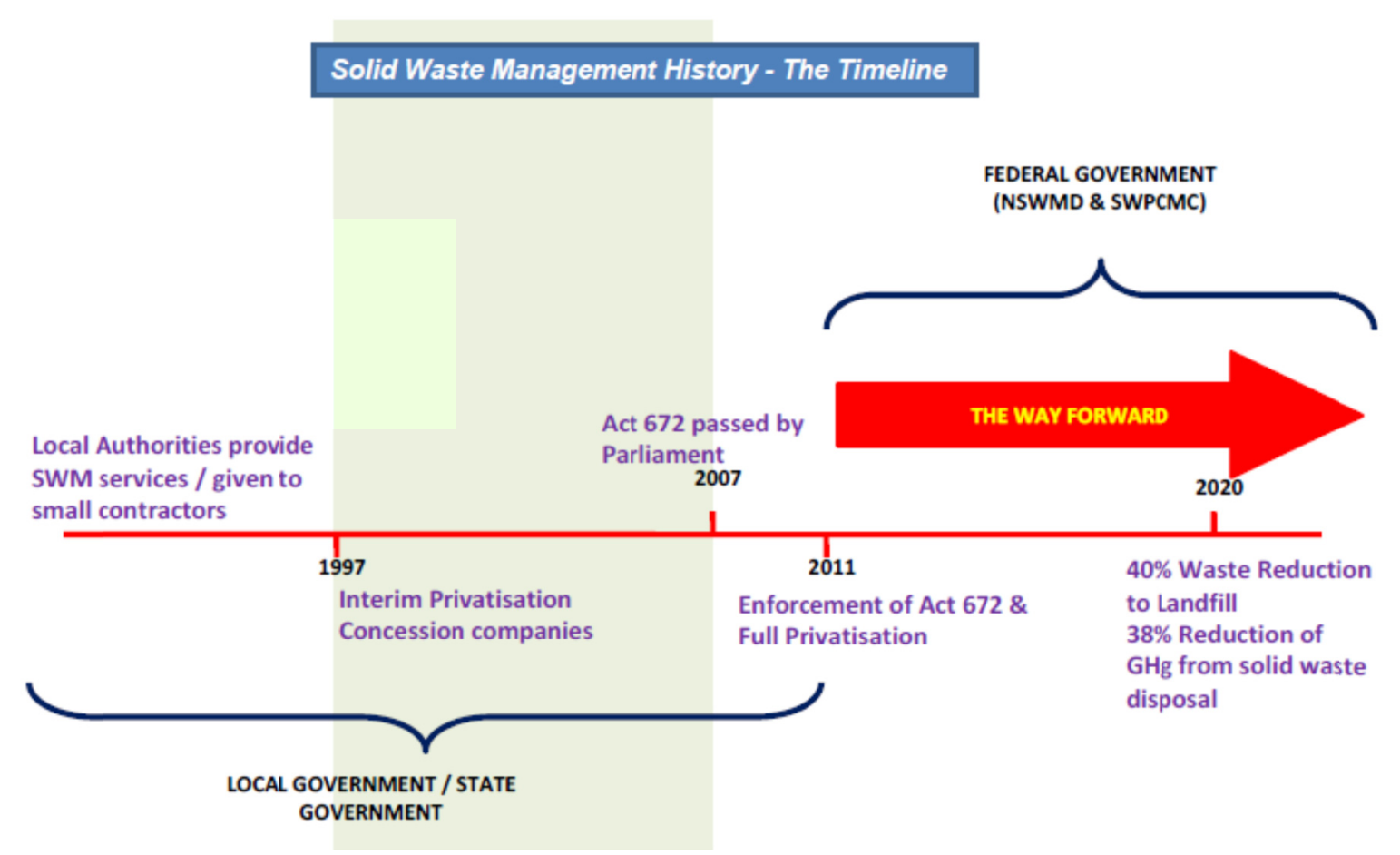

Figure 1. Timeline in the history of solid waste management (MHLG, 2012)

In 2007, a bill (Act 672) was passed by the parliament, which empowers the federal government to take over this responsibility. The implementation of the Act commenced in September, 2011 through the ministry of housing and local government, which was charged with the responsibilities for the management of the controlled solid waste (Tarmudi et al., 2012). The Department of National Solid Wastes Management (DNSWM) and the Solid Waste and Public Cleansing Management Corporation (SWPCMC) were established to make and execute policies relating to SWM respectively. The government is currently making efforts, according to its plan for reducing the amount of solid wastes disposed in landfills by $40 \%$ and greenhouse gases (GHG) from solid waste disposal by 38\% (MHLG, 2012). Under the new practice, the ministry of housing and local government has contracted the solid waste management activities to companies based on regions (Johari et al., 2012) as shown in Table 1.

Table 1. Solid waste management contractors in Malaysia

\begin{tabular}{lll}
\hline Region & Consortium & Operation coverage \\
\hline $\begin{array}{l}\text { Central and Eastern Peninsular } \\
\text { Malaysia }\end{array}$ & Alam Flora Sdn. Bhd. & $\begin{array}{l}\text { Kuala Lumpur, Selangor, Pahang, } \\
\text { Kelentan, Terrangganu. }\end{array}$ \\
$\begin{array}{l}\text { Southern Peninsular Malaysia } \\
\text { Northern Peninsular Malaysia }\end{array}$ & SW Environment Sdn. Bhd. & Johor, Negeri Sembilan, Melaka. \\
East Malaysia & Eastern Waste Management Sdn. & Sabah, Sarawak and Labuan. \\
& Bhd. & \\
\hline
\end{tabular}

Alam Flora Sdn. Bhd. handles the northern parts and SWM Sdn. Bhd. handles collection and disposal of MSW generated in the southern region of peninsular Malaysia such as Johor State among others. 


\section{Municipal Solid Wastes in Malaysia}

\subsection{Municipal Solid Waste Generation and Population Growth}

Municipal solid waste generation has been continuously on the increase and as such its management has been a big problem up to today in Malaysia due to its rapid increase in the volume and composition (Agamuthu et al., 2009). It was reported in 2003; that the average amount of municipal solid waste generation per capita per day ranged between $0.5-0.8 \mathrm{~kg}$ but in the recent past the range has increased to between $0.5-2.5 \mathrm{~kg}$, especially in the major cities such as Kuala Lumpur and Petaling Jaya (Kathrvale et al., 2003; Agamuthu et al., 2009). The national strategic plan on solid waste management estimated that the waste generation rate increases by $3.59 \%$ per year based on the population growth projections for the period of $2002-2020$. Thus, based on that projection, the total waste generated in peninsular Malaysia was 23000 tons/day in 2010 and 25000 tons/day in 2012. In 2020 , the amount of waste to be generated has been estimated to reach 30000 tons/day (MHLG, 2010). It was also reported that the current amount produced has almost reached the 2020 target of 30000 (Agamuthu \& Fauziah, 2011). This high generation rate in Malaysia is attributed to the rapid economic growth, rural-urban migration, changing lifestyles that have been experienced in the recent past. Furthermore, the Government in its 10th Malaysia plan has set some targets for waste reduction, reuse, recovery and recycling so as to minimize the quantity to be landfilled; a plan toward its realization of the developed nation status come 2020 .

Population growth and solid waste generation are directly related. In other words, as population increases, the generated amount of waste also increases. Figure 2 shows this relationship in Malaysia for years $2000-2010$.

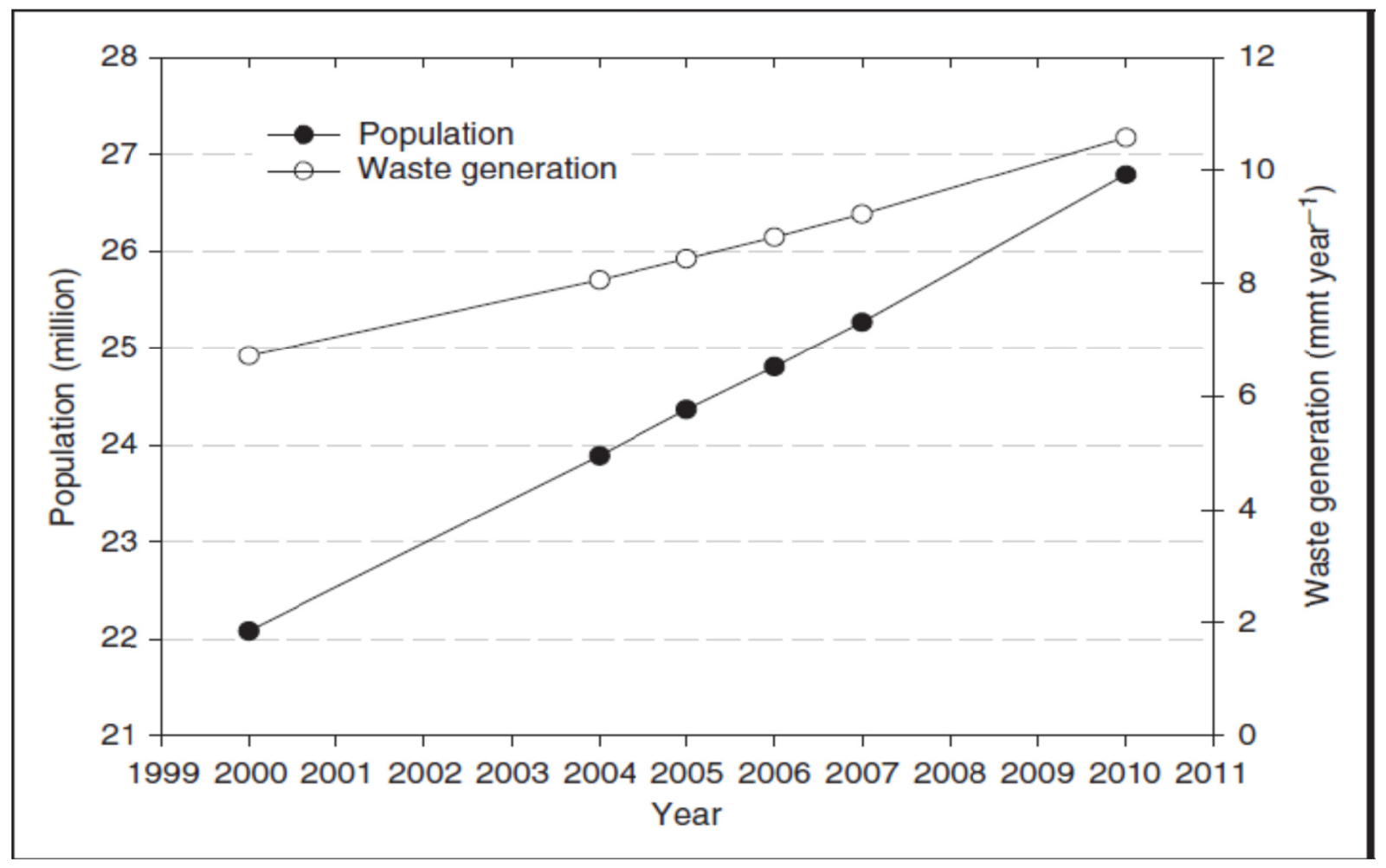

Figure 2. Relationship between population growth and solid waste generation (Abushamala et al., 2010) 
The amounts of municipal solid waste generated from 1996-2009 by state in Malaysia is shown in Table 2 .

Table 2. Generation of municipal solid waste in Malaysia by State (1996-2009) (Agamuthu \& Fauziah, 2011)

\begin{tabular}{lcccccccc}
\hline State & \multicolumn{7}{c}{ Municipal Solid Waste Generation (tons/day) } \\
\cline { 2 - 8 } & 1996 & 1998 & 2000 & 2002 & 2004 & 2006 & 2008 & 2009 \\
\hline Johor & 1613 & 1786 & 1915 & 2093 & 2255 & 2430 & 2578 & 2655 \\
Kedah & 1114 & 1215 & 1324 & 1447 & 1559 & 1680 & 1782 & 1835 \\
Kelantan & 871 & 950 & 1034 & 1131 & 1213 & 1302 & 1382 & 1423 \\
Melaka & 433 & 480 & 515 & 563 & 605 & 650 & 690 & 711 \\
Negeri Sembilan & 637 & 695 & 757 & 828 & 890 & 957 & 1015 & 1046 \\
Pahang & 806 & 879 & 957 & 1046 & 1125 & 1210 & 1284 & 1322 \\
Perak & 1284 & 1402 & 1527 & 1669 & 1795 & 1930 & 2048 & 2109 \\
Perlis & 165 & 180 & 196 & 214 & 230 & 247 & 262 & 270 \\
Pulau Pinang & 916 & 999 & 1088 & 1089 & 1278 & 1375 & 1458 & 1502 \\
Selangor & 2380 & 2595 & 2827 & 3090 & 3322 & 3573 & 3790 & 3904 \\
Terrengganu & 743 & 811 & 883 & 965 & 1038 & 1116 & 1184 & 1219 \\
Kuala Lumpur & 2105 & 2305 & 2520 & 2755 & 3025 & 3323 & 3525 & 3631 \\
WP Labuan & NA & NA & 46 & 70 & 74.3 & 81.2 & 86.1 & 88.7 \\
Sabah & NA & NA & NA & 1905 & 2021 & 2208 & 2343 & 2413 \\
Sarawak & NA & NA & NA & 1905 & 2021 & 2208 & 2343 & 2413 \\
Total & 13070 & 14589 & 15587 & 21452 & 23073 & 24969 & 26489 & 27284 \\
\hline
\end{tabular}

Note: NA - Not available.

The table shows that Selangor state produced the highest quantity of municipal solid waste, followed by Kuala Lumpur and Johor. The total amount of waste presented in Table 2 (27284) is greter than the one reported by the MHLG (2010). The trend shows that the waste generation keeps on increasing on yearly basis.

\subsection{Composition of Municipal Solid Waste}

Solid waste composition refers to the various constituents that the waste contains. The composition of municipal solid waste is one of the factors to be considered before proposing any management option. Though it changes over time, it also assists in predicting the future trends. It was reported that the waste compositions in most countries of the world is normally dominated by organic matter followed by paper and plastics. It was also reported that in all the Asian countries except Japan, the waste is dominated by organic material, comprising approximately $75 \%$ of the total waste stream (Agamuthu \& Fauziah, 2007). In Malaysia, most recent data on solid waste compositions are scarce. This resulted in most researchers and government officials using or presenting old ones or otherwise estimates (Tarmudi et al., 2012; Johari et al., 2012). The municipal solid waste contributions by the various sources are presented in Figure 3. It shows that the residential source contributes the highest portion of the solid waste produced in Malaysia, followed by commercial sector. The domestic, commercial and municipal (street sweepings, etc.) are largely referred to as the MSW (Tarmudi et al., 2012). 


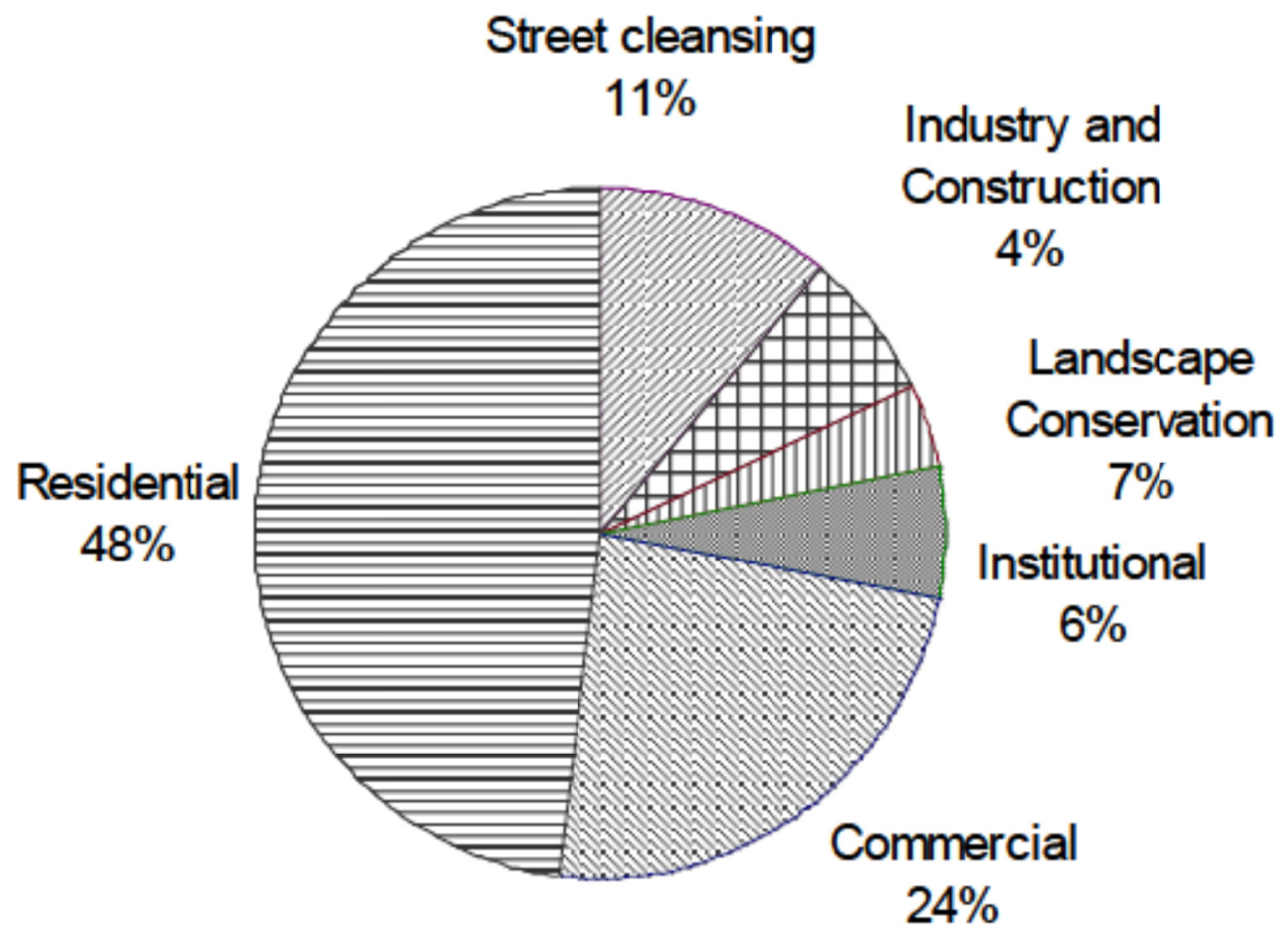

Figure 3. Composition of Municipal solid wastes by sector in Malaysia (Saeed et al., 2009)

The material compositions of municipal solid waste obtained from various studies and sites in Malaysia from 2001 to 2010 is shown in Table 3.

Table 3. The material composition of municipal solid waste from various studies and sites (Chua et al., 2011)

\begin{tabular}{lccccccccc}
\hline Components & $2001^{\mathrm{a}}$ & $2001^{\mathrm{b}}$ & $2002^{\mathrm{c}}$ & $2003^{\mathrm{c}}$ & $2004^{\mathrm{d}}$ & $2005^{\mathrm{e}}$ & $2005^{\mathrm{f}}$ & $2007^{\mathrm{g}}$ & $2010^{\mathrm{h}}$ \\
\hline $\begin{array}{l}\text { Food waste } \\
\text { \& organics }\end{array}$ & 68.4 & 32 & 56.3 & 37.4 & 49.3 & 45 & 47.5 & 42 & 43.5 \\
Mix Plastic & 11.8 & 16 & 13.1 & 18.9 & 9.7 & 24 & $\mathrm{NA}$ & 24.7 & 25.2 \\
Mix Paper & 6.3 & 29.5 & 8.2 & 16.4 & 17.1 & 7 & 18.5 & 12.9 & 22.7 \\
Textiles & 1.5 & 3.4 & 1.3 & 3.4 & NA & NA & 2.13 & 2.5 & 0.9 \\
Rubber and & 0.5 & 2 & 0.4 & 1.3 & NA & NA & NA & 2.5 & NA \\
Leather & & & & & & & & & \\
Wood & 0.7 & 7 & 1.8 & 3.7 & NA & NA & 4.41 & 5.7 & NA \\
Yard wastes & 4.6 & NA & 6.9 & 3.2 & NA & NA & 2.72 & NA & NA \\
Ferrous & 2.7 & 3.7 & 2.1 & 2.7 & 2 & 6 & NA & 5.3 & 2.1 \\
Glass & 1.4 & 5.5 & 1.5 & 2.6 & 3.7 & 3 & NA & 1.8 & 2.6 \\
Pampers & NA & NA & NA & 5.1 & NA & NA & NA & 3.81 & NA \\
Other & 2.1 & 1.9 & 8.4 & 5.3 & 18.2 & 15 & 21.93 & 2.6 & 1.8 \\
Total & 100 & 100 & 100 & 100 & 100 & 100 & 100 & 100 & 100 \\
\hline
\end{tabular}

Note: NA - Not available. 
a) Hassan et al "Solid waste management in Southeast Asian countries with special attention to Malaysia", 8th international waste management and landfill symposium 2001. A data taken from Kuala Lumpur

b) Wan Ramle Wan A. Kadir “A comparative analysis of Malaysian and the UK waste policy and institutional framework" by Waste Management conference, 2001

c) Nazeri A.R a report on solid waste composition from a study conducted at Tamn Beringin landfill in 2000

c) S. Kathirvale et al "Energy potential from municipal waste in Malaysia" Journal of Renewal Energy, 2003 (data for kuala lumpur)

d) JICA “The Study on National Waste Minimisation in Malaysia” July 2004 -June 2006

e) As published by Ministry of Housing and Local government's website based on 2005

f) Sampling by Bukit Tagar Sanitary Landfill 2005

g) Muhammad Abu Eusuf et al "An overview on waste generation characteristic in some selected local authorities in Malaysia”

proceedings of international Conference on Sustainable Solid Waste Management September 2007

h) Siti Rohana M. Yatim "Household Solid Waste Characteristic and management in low cost apartment in petaling Jaya, Selangor, 2010.

The results in Table 3 show that organics are the main component of the solid waste in Malaysia. The organic components of the waste ranged from $32 \%$ to $68.4 \%$ based on the findings of the different authors. Also, other components such as paper, plastics and glass ranged from $6.3 \%$ to $29.5 \%, 11.8 \%$ to $25.2 \%$, and $1.4 \%$ to $5.5 \%$ respectively. The current composition trend also shows that food, paper and plastic wastes comprised about $70 \%$ of the total solid wastes produced in most places/cities in Malaysia (Sakawi, 2011; Agamuthu \& Fauziah, 2007). In addition, the putrescible component of the wastes was found to contribute approximately $46 \%$, followed by paper waste with 14\% and plastic based waste 15\% in the year 2007 (Agamuthu \& Fauziah, 2011). This gradual decrease in the amount of organics and the increase in the amounts of paper, plastics and glass signifies that Malaysia is in a transitional period to attain the developed nation status. This was based on the fact that wastes in developed countries, mostly contain more packaging materials and low percentage of organics (MHLG, 2010).

\subsection{Storage and Handling}

The storage and handling are one of the key aspects of effective solid waste management (Imam et al., 2008). In Malaysia, different types of containers and bins are used for storing solid wastes, but mainly depending on the source (Lau, 2004). In case of the household, the bins are usually placed outside either in front or at the backyards of the houses. High rise apartments or flats use specially designed chutes, communal storage or roll-on-roll-offs. In commercial areas, large movable or stationary containers greater than $12 \mathrm{~m}^{3}$ are used.

\subsection{Collection and Transportation}

Municipal solid waste collection in Malaysia was the responsibility of the local authorities prior to the taking over by the federal government. The local authorities either contracted or directly provide the collection services. During this period, about $50 \%$ of the municipal operating budget was reported to have been spent on the management of municipal solid waste and out of this, $70 \%$ is spent on the collection of wastes (UNEP, 2002). This clearly indicates that collection consumes huge sum of money and the most expensive task. In the recent past, that is after the federal government took over such responsibility, it contracted out the management services to private contractors on a regional basis under its privatization program. This is done in order to improve the quality of services. The collection frequency varies from every two days at the residential areas to daily basis at the communal/commercial areas (UNDP, 2008).

The collection services are impressive based on the fact that about $76 \%$ of the produced municipal solid wastes were reported to be collected (Fauziah et al., 2004; Manaf et al., 2009). Different types of collection vehicles are used for the collection of municipal solid wastes in Malaysia. The most common ones include open lorry trucks, and compactor type trucks.

\subsection{Waste Treatment and Disposal}

In the past, open dumping and burning of wastes were the most common practices in Malaysia, until the early 1990's when landfills gradually became the preferred solution. Landfills are the most common municipal solid waste (MSW) disposal means despite the tremendous efforts currently made towards recovery of both materials and energy from these wastes worldwide (Al Ansari, 2012). Like in all other developing economies, Malaysia disposes most of its waste by landfilling, although there is a serious effort and plans in exploring other disposal 
means (Johari et al., 2012). Landfills remain and will continue to remain an integral part of most solid waste management plan but if not done in a sanitary manner can pose risks to both life and the environment. For instance, in 2006, drinking water source was contaminated by leachate from solid waste landfill in Klang valley, Malaysia. This necessitated the government to, without delay, order for the immediate closure of many unsafe landfills across the country, upgraded some and constructed new ones as well (Agamuthu \& Fauziah, 2011).

Various methods and targets of solid waste management in Malaysia were proposed as shown in Table 4.

Table 4. Targets of Solid Waste disposal in Malaysia (Agamuthu et al., 2009)

\begin{tabular}{lccc}
\hline Method & $2002(\%)$ & $2006(\%)$ & 2020 Target $(\%)$ \\
\hline Recycling & 5.0 & 5.5 & 22.0 \\
Composting & 0 & 1.0 & 8.0 \\
Incineration & 0 & 0 & 16.8 \\
Inert landfill & 0 & 3.2 & 9.1 \\
Sanitary landfill & 5.0 & 30.9 & 44.1 \\
Others (ordinary & 90.0 & 59.4 & 0 \\
dumping, etc) & & & 100 \\
Total & 100 & 100 & \\
\hline
\end{tabular}

The proposal was made over a decade, but the level of achievement has been low up to today. For example, the recycling rate as shown in the table only increased by $0.5 \%$ from year 2002 to 2006 . Also, composting rate from zero to only $1 \%$ and incineration remained zero from 2002 to 2006 . This shows that the level of progress has been low. In 2020 , it is the plan of the government to reduce landfilling to about $50 \%$, by increasing composting to $8 \%$, incineration to $16.8 \%$ and recycling to $22 \%$ respectively. The realization of this plan, looking at the level of progress, is doubtful unless urgent measures are taken.

In 2011, there were 296 landfills all over the country and about 166 are still operating. It was also reported that out of the 166 operating landfills, only 11 are sanitary and capable of preventing environmental degradation resulting from landfill gas and leachate escape to the environment (Johari et al., 2012; NSWMD, 2011). Landfills are however not sustainable solutions due to land scarcity, rising costs and other constraints. The government, as stated in the Tenth Malaysia Plan $(2011$ - 2015), intends to close and rehabilitate most of the existing unsanitary landfills across the nation. In addition, there were plans to: upgrade some of the existing landfill sites to sanitary landfills; build integrated material recovery facilities; build new sanitary landfills and transfer stations (Tarmudi et al., 2012). As a result of passing the law of the solid waste and public cleansing management Act 2007, the numbers of landfill in the country were reported to have reduced (Fauziah and Agamuthu, 2012). Table 5 shows the estimated number of municipal solid waste disposal sites by state in Malaysia.

Table 5. Number of landfill sites by states in Malaysia (NSWMD, 2011)

\begin{tabular}{lccc}
\hline \multicolumn{1}{c}{ State } & Operational & Closed & Total \\
\hline Johor & 14 & 23 & 37 \\
Kedah & 9 & 6 & 15 \\
Kelantan & 13 & 6 & 19 \\
Melaka & 2 & 5 & 7 \\
Negeri Sembilan & 7 & 11 & 18 \\
Pahang & 16 & 16 & 32 \\
Perak & 17 & 12 & 29 \\
\hline
\end{tabular}




\begin{tabular}{lccc}
\hline Perlis & 1 & 1 & 2 \\
Pulau Pinang & 2 & 1 & 3 \\
Sabah & 19 & 2 & 21 \\
Sarawak & 49 & 14 & 63 \\
Selangor & 8 & 14 & 22 \\
Terengganu & 8 & 12 & 20 \\
Kuala Lumpur & 0 & 7 & 7 \\
Labuan & 1 & 0 & 1 \\
Total & 166 & 130 & 296 \\
\hline
\end{tabular}

The Table 5 also shows that Sarawak has the highest number of landfill sites followed by Johor with 63 and 37 sites respectively. Sarawak is not the most populated or the highest waste generator among all the states but has the highest number of landfill sites. This is as a result of the availability of vast lands all over the state. It was further reported that $50 \%$ of the overall national waste amount is openly dumped, $30 \%$ is landfilled, $10 \%$ is composted, 5\% percent is incinerated and another 5\% is recycled (Ngoc and Schnitzer, 2009). In the developed nations nowadays, more priority is given to the disposal of wastes as close as possible to the points of generation (Agamuthu \& Fauziah, 2007). This is to minimize costs and environmental pollutions.

\subsection{Composting in Malaysia}

Composting is the biological degradation of organic substances by microorganisms (Saheri et al., 2009). It is a natural phenomenon for the stabilization of organic waste matter which results in the production of high nutrient material popularly referred to as compost or humus. It was reported as one of the most cost effective and sustainable municipal solid waste management options over the traditional means like landfilling or burning as it enables recycling of potential plant nutrients which in most cases dominate wastes in developing countries (Bundela et al., 2010). This product has varying uses from agricultural productions, horticulture and in some cases for land reclamations, more especially for the reclamation of burrow pits and other land depressions.

Municipal solid wastes generated in Malaysia contain high percentage of organics (45-60\%) with a moisture content of about 55\% (Fauziah and Agamuthu, 2012). This amount of moisture contained in this wastes falls within the range of $40-60 \%$ that is suitable for microbial degradation (SANDEC, 2003), hence composting would be a better option to treat this high amount of organics in the wastes (Johari et al., 2012). However, based on the current disposal methods practiced, composting is not carried out at large scale and is rarely utilized. Despite the fact that it is not well practiced in Malaysia, compost is sold from RM180 to RM1000 per ton depending on market demand and compost quality (NSWMD, 2011). A study was carried out on the composting of wet-market wastes in Selangor (Agamuthu \& Fauziah, 2007). This study although done at a pilot scale shows that these wastes have great potentials for high quality compost and revenue generation. The compost produced was sold at USD0.55 (RM2.00) per kg, generating gross revenue of USD4,210 (RM16,000) per day. The approximate cost of composting 15 tonnes of the market wastes was USD790 (RM3,000), the net revenue was estimated to be USD3,420 (RM13,000) and a total of USD0.8 million (RM3.1 million) could be generated annually when fully commercialized.

Moreover, a large scale composting plant was also established in Kota kinabalu in the state of Sabah which uses aerobic composting method to treat about 300 tons per day (45000 tons per year) of the organic fractions of municipal solid wastes. It was also estimated that the project has potentials for greenhouse gas emissions reduction of about 73738 tons of $\mathrm{CO}_{2}$-e (CDM, 2006).

\subsection{Incineration in Malaysia}

The composition of municipal solid wastes in Malaysia shows that combustibles such as paper and plastics are high, next to organics with a calorific value between 1500 and $2600 \mathrm{kcal} / \mathrm{kg}$. The land for the construction of landfills, which is the most currently practiced method is becoming scarce and expensive as well. Also, most of the existing ones that have not filled to their design capacities are about reaching it. These factors among others favour the use of incineration. But one of the most important issues making incineration more difficult is that of high moisture contents of municipal solid wastes produced in Malaysia which ranges from $50-60 \%$ and the highly humid nature of the country. The Malaysian government has made so much effort to acquire and install incinerators in many parts of the country despite its high capital and operational costs, but till now has not been 
realized. As a result, there is no incineration of municipal solid wastes in Malaysia except on the islands and highland (Agamuthu et al., 2009b). Though, small-scale incinerators of rotary kiln type are used in some of the tourism spots: Pulau Langkawi (100 ton/day), Pulau Labuan (60 ton/day), Cameron Highlands (40 ton/day), Pulau Pangkor (20 ton/day) and Pulau Tioman (10 ton/day). On the other hand, about $90 \%$ of wastes produced in Singapore were reported to be incinerated after recovery of the recyclables, use of incinerators could therefore be possible in Malaysia because these wastes have similar characteristics (Bai \& Sutanto, 2002).

\section{Waste Minimization Potentials in Malaysia}

\subsection{Reduce/Reuse}

Source reduction is to plan and execute minimization of waste right at the generation stage and is the most preferred option according to the waste management strategy. It focuses on reducing the volume and/or toxicity of waste generated as well as switching to reusable products and packagings. However, the option is often opposed by consumer society, where the consumption of products is encouraged (Bagdie et al., 2012).

Waste reduction can be achieved at several levels, such as reduction of per capita waste generation through awareness creation, government policy initiatives, source separation and separate collection for recyclable, and recovery of recyclable materials at the disposal sites (Badgie et al., 2012). Reuse on the other hand is to repeat the use of a material or a product more than once. This practice is more encouraged because of its benefits for the fact that no cost and less energy are required for cleaning and refurbishing. Reusing materials and products saves energy and water, reduces pollution, and lessens society's consumption of natural resources compared to the use of single-use products and materials. Reuse of materials and products is regarded as more socially desirable than recycling the same materials. For example, both plastic and glass bottles are reused once or several times. Also, cardboard boxes that are used for shipping products can be folded and sent back to the manufacturer to be reused for shipping the same or other products (Sridevi et al., 2012).

\subsection{Solid Waste Recycling}

Recycling of municipal solid waste (MSW) has been recognized as the "most environmentally sound" strategy for dealing with MSW, only second to the preventive strategy of source reduction and reuse (USEPA, 2004). Recycling of waste nowadays is very much acknowledged for the fact that thousands of people earn their means of survival through it (Wilson, 2007). On realizing how important recycling is, the federal government of Malaysia first launched recycling programs in 1993. It was also re-launched in December 2000 by the Ministry of Housing and Local Government and $11^{\text {th }}$ November of every year declared as the National Recycling Day. To attain the proposed recycling rate of about $20 \%$ or more, it was reported that the populace need to intensively support and participate in the recycling activities. By this, more of the municipal solid wastes would be diverted from being disposed into landfills (Manaf et al., 2009).

Recycling has been a well-established business not only in Malaysia but also in other parts of the world (Al-Salem et al., 2009). Until now, people have been collecting old newspapers, glass bottles, metals and other recyclables for recycling purposes. In this business, many players are involved; ranging from small primary paper collectors or landfill scavengers to a medium scale scraps metal middleman and a large recycling industry (Chong, 2006). It was also reported that the waste standards for recyclable materials, recycled products and recycling industry standards in the waste minimization plan or strategy are also not well addressed (Mohamed, 2012). Despite the fact that the larger portions of the municipal solid wastes produced in Malaysia are recyclables, which includes paper, plastics among others representing about $60 \%$ of the total waste volume, only about 5-5.5\% recycling rate was reported to have been attained (Agamuthu et al., 2009b; Fauziah et al., 2004; Saeed et al., 2009). In order to attain significant level in recycling, people's attitude is an important factor to be considered (Begum et al., 2009). In a related development, previous studies show that more than $70 \%$ of Malaysians are aware of the recycling idea but less than $25 \%$ actually participate (Fauziah et al., 2004). The current government target is to attain solid wastes recycling rate of $22 \%$ towards the year 2020 (NSWMD, 2011) While some developed countries in Asia have succeeded in recovering and recycling most of the recyclables they produce, Malaysia has been far left behind. For example, Korea has attained waste recycling rates of $44-50 \%$ between 2002-2008 and Singapore from $44 \%$ in 2002 to $48 \%$ in 2004 and expected to reach $60 \%$ in 2012 (Chong, 2006).

\subsubsection{Revenue from Recyclables}

The waste composition data and the prices of the recyclables used for estimating the revenues were the ones used by the Ministry of Housing and Local Government in 2005 (MHLG, 2012). Labour, transportation and other 
overhead costs were not considered. The estimates of the economic potentials of some recyclables in Malaysia are as shown in Table 7.

Table 6. Economic potentials estimate of some recyclables in Malaysia (MHLG, 2012)

\begin{tabular}{lcccc}
\hline Composition & Percentage (\%) & $\begin{array}{c}\text { Amount } \\
\text { (tonnes/year) }\end{array}$ & $\begin{array}{l}\text { Market price } \\
(\mathrm{RM} / \mathrm{kg})\end{array}$ & $\begin{array}{l}\text { Values(Million } \\
\mathrm{RM})^{*}\end{array}$ \\
\hline Papers & 17.1 & $1,846,800$ & 0.20 & 369.36 \\
Plastics & 9.1 & 982,800 & 0.30 & 294.84 \\
Glass & 3.7 & 399,600 & 0.05 & 19.98 \\
Aluminium & 0.4 & 43,200 & 2.00 & 86.40 \\
Scrap Metals & 1.6 & 172,800 & 0.50 & 86.40 \\
Other & 68.1 & $7,354,800$ & $\mathrm{NA}$ & $\mathrm{NA}$ \\
non-recyclables & & & & 857.0 \\
Total & & & & \\
\hline
\end{tabular}

Note: $N A$ - Not available.

* Estimated.

$1 \mathrm{USD}=3$ Malaysian Ringgit (RM).

The revenue generation potentials of recyclables in Malaysia were determined based on the 30000 tons per day of municipal solid waste generated. The yearly amount of recyclables produced is about 3.5 million tons. Revenue of about RM857 (USD286) million can be generated from the recyclables, if recovered and sold. This amount could be used to supplement the money spent on the management or alternatively be used to donate to various charities.

\section{Conclusion}

Malaysia has been making tremendous efforts in order to proffer solutions to the growing environmental problems posed by solid wastes. This was necessitated by the increasing quantity and complexity in the compositions of the solid wastes produced in the country. The government's various plans for solid waste management clearly show that it is fully committed. Currently, the bulk of the wastes are landfilled in both sanitary and unsanitary landfills. Most of these landfills have reached or about reaching their lifespans. In addition, acquiring new sites has become a very difficult task owing to land scarcity and high cost which was brought about by the country's economic growth. The recycling rate is low and only a little portion of the generated waste is composted with virtually no incineration done except on the Islands. Since the greater part of the solid waste is organic in nature, composting would be a better option followed by the intensification of recycling. These options, if fully utilized would greatly minimize the amount of wastes being disposed in landfills and also minimizes the environmental impacts.

\section{Acknowledgments}

The support received from the Ministry of Higher Education, Malaysia (GUP grant VOT No. 05H04) and the Universiti Teknologi Malaysia is highly recognized and appreciated.

\section{References}

Abushammala, F. M., Noor, E. A., Basri, H. B., Ahmed, H. El-S., \& Abdul, A. H. K. (2010). Regional landfills methane emission inventory in Malaysia. Waste Management \& Research, 1-11.

Agamuthu, P. (2001). Solid Waste: Principles and Management with Malaysian case studies. University of Malaya press, Kuala Lumpur, 44.

Agamuthu, P., \& Dennis, V. (2011). Policy trends of extended producer responsibility in Malaysia. Waste Manag Res 2011, 29, 945. http://dx.doi.org/10.1177/0734242X11413332

Agamuthu, P., \& Fauziah, S. H. (2007). Sustainable Management of Wet Market Waste. Proceedings of the International Conference on Sustainable Solid Waste Management. 5 - 7 September 2007, Chennai, India. pp.239-243.

Agamuthu, P., \& Fauziah, S. H. (2011). Challenges and issues in moving towards sustainable landfilling in a 
transitory country- Malaysia. Waste Management and Resources, 29, 13-19. http://dx.doi.org/10.1177/0734242X10383080

Agamuthu, P., Fauziah, S. H., \& Kahlil, K. (2009). Evolution of Solid Waste Management in Malaysia: Impacts and Implications of the Solid Waste Bill, 2007. J Mater Cycles Waste Management, 11, 96-103. http://dx.doi.org/10.1007/s10163-008-0231-3

Al.Ansari, M. S. (2012). Improving Solid Waste Management in Gulf Co-operation Council States: Developing Integrated Plans to Achieve Reduction in Greenhouse Gases. Modern Applied Science, 6(2), 60-68.

Al-Salem, S. M., Lettieri, P., \& Baeyens, J. (2009). Recycling and recovery routes of plastic solid waste (PSW): A review. Waste Management, 29, 2625-2643. http://dx.doi.org/10.1016/j.wasman.2009.06.004

Badgie, D., Samah, M. A., Latifah, A. M., \& Azizi, B. M. (2012). Assessment of Municipal Solid Waste Composition in Malaysia: Mangement, Practice and Challenges. Pol. J. Environ. Stud., 21(3), 539-547.

Bai, R., \& Sutanto, M. (2002). The practice and challenges of solid waste management in Singapore. Waste Management, 22, 557-567. http://dx.doi.org/10.1016/S0956-053X(02)00014-4

Begum, R. A., Siwar, C., Pereira, J. J., \& Jaafar, A. H. (2009). Attitude and behavioral factors in waste management in the construction industry of Malaysia. Resources, Conservation and Recycling, 53, 321-328. http://dx.doi.org/10.1016/j.resconrec.2009.01.005

Bundela, P. S., Gautam, S. P., Pandey, A. K., Awasthi, M. K., \& Sarsaiya, S. (2010). Municipal solid waste management in Indian cities - A review. International Journal of Environmental Sciences, 1(4).

Chong, C. L. (2006). Waste to Wealth, How it Works in Malaysia. Impak, 2, 10-12.

Chua, K. H., Sahid, E. J. M., \& Leong, Y. P. (2011). Sustainable Municipal Solid Waste Management and GHG Abatement in Malaysia. ST-4: Green \& Energy Management. (C15-ICIT.

Clean Development Mechanism Project Design Document Form (CDM-PDD) Version 03 - in effect as of: 28 July 2006.

Eltayeb, T. K., Zailani, S., \& Ramayah, T. (2011). Green supply chain initiatives among certified companies in Malaysia and environmental sustainability: Investigating the outcomes. Resources, Conservation and Recycling, 55, 495-506. http://dx.doi.org/10.1016/j.resconrec.2010.09.003

Fauziah, S. H., Simon, C., \& Agamuthu, P. (2004). Municipal Solid Waste Management in Malaysia - Possibility of improvement? Malaysian Journal of Science, 23(2), 61-70.

Fauziah, S. H., \& Agamuthu, P. (2012). Trends in sustainable landfilling in Malaysia, a developing country, Waste Management \& Research, 1-8.

Hezri, A. A., \& Hasan, M. N. (2006). Towards sustainable development? The evolution of environmental policy in Malaysia. Natural Resources Forum, 30, 37-50. http://dx.doi.org/10.1111/j.1477-8947.2006.00156.x

Imam, A., Mohammed, B., Wilson, D. C., \& Cheeseman, C. R. (2008). Solid waste management in Abuja, Nigeria. Waste Management, 28, 468-472. http://dx.doi.org/10.1016/j.wasman.2007.01.006

Johari, A., Ahmed, S. I., Hashim, H., Alkali, H., \& Ramli, M. (2012). Economic and environmental benefits of landfill gas from municipal solid waste in Malaysia. Renewable and Sustainable Energy Reviews, 16, 2907-2912. http://dx.doi.org/10.1016/j.rser.2012.02.005

Kathirvale, S., Muh Yunus, M. N., Sopian, K., \& Samsuddin, A. H. (2003). Energy Potential from Solid Waste in Malaysia. Renewable Energy, 29, 59-567.

Lau, L. (2004). Case Study on the Management of Waste Materials in Malaysia. Forum Geoökologie, 15(2). Verband für Geoökologie [Ed.], Bayreuth.

Manaf, L. A., Mohd, A. A. S., \& Nur, I. M. Z. (2009). Municipal Solid Waste Management in Malaysia: $\begin{array}{llll}\text { Practices and } \text { Challenges. Waste } & \text { 2902-2906. }\end{array}$ http://dx.doi.org/10.1016/j.wasman.2008.07.015

Ministry of Housing and Local Government. (2006). The Study on National Waste Minimisation in Malaysia. Final Report - Summary.

Ministry of Housing and Local Government. (2010). Strategic Solid Waste Management: The Malaysian Approach. Keynote address by Secretary General. Sunway Hotel Resort and Spa, Kuala Lumpur.

Ministry of Housing and Local Government. (2012). Solid Waste Management in Malaysia: The Way Forward. 
19th July, 2012: Waste Management 2012.

Ministry of Housing and Local Government, Malaysia (2005). National Strategic Plan for Solid Waste Management.

Mohamed, A. F. (2012). Standard for Waste Recycling Industry in Malaysia: Towards Sustainability of Recycling Industry. The 7th Asian Pacific Landfill Symposium October 8th - 11th, 2012, Bali, Indonesia.

National Solid Waste Management Department (NSWMD). (2011). Landfill sites in Johor, Ministry of Housing and Local Government. Kuala Lumpur, Malaysia. Retrieved from www.kpkt.gov.my accessed 15/06/2011

Ngoc, U. N., \& Schitzer, H. (2009). Sustainable solutions for solid waste management in Southeast Asian countries. Waste Management, 29, 1982-1995. http://dx.doi.org/10.1016/j.wasman.2008.08.031

Pukkalanun, N., Inkapatanakul, W., Piputsitee, C., \& Chunkao, K. (2013). An Analysis of the Environmental Vulnerability Index of a Small Island: Lipe Island, Kho Sarai Sub-District, Mueang District, Satun Province, Thailand. Modern Applied Science, 7(2), 33-38. http://dx.doi.org/10.5539/mas.v7n2p33

Saeed, M.O., Hassan M. N., \& Mujeebu, M. A. (2009). Assessment of municipal solid waste generation and recyclable materials potential in Kuala Lumpur, Malaysia. Waste Management, 29(7), 2209-2213. http://dx.doi.org/10.1016/j.wasman.2009.02.017

Saheri, S., Mir, M. A., Basri, N. E. A., Begum, R. A., \& Mahmood, N. Z. B. (2009). Solid Waste Management by considering composting potential in Malaysia toward a green country. Journal of Social Sciences and Humanities, 4(1), 48-55.

Sakawi, Z. (2011). Municipal Solid Waste Management in Malaysia: Solution for Sustainable Waste Management. Journal of Applied Sciences in Environmental Sanitation, 6(1), 29-38.

SANDEC/EAWAG---IWMI. (2003). Co-composting of Faecal Sludge and Municipal Organic Waste. A Literature and State-of-Knowledge Review.

Sridevi, V., Modi, M., Chandana, L., \& Kesavarao, L. (2012). A Review on Integrated Solid Waste Management. International Journal of Engineering Science \& Advanced Technology [IJESAT], 2(5), 1491-1499.

Tarmudi, Z., Abdullah, M. L., \& Tap, A. O. M. (2012). A Review of Municipal Solid Waste Management in Malaysia. Jurnal Teknologi, 57, 41-56. http://dx.doi.org/10.11113/jt.v57.1252

U.S. EPA. (2004). Resource Conservation Challenge - A Year of Progress, EPA530-R-04-001, February 2004.

Uiterkamp, B. J. S., Azadib, H., \& Hoc, P. (2011). Sustainable recycling model: A comparative analysis between India and Tanzania. Resources, Conservation and Recycling, 55, 344-355. http://dx.doi.org/10.1016/j.resconrec.2010.10.009

UNDP. (2008). Malaysia Developing a Solid Waste Management Model for Penang. United Nations Development Programme, Malaysia.

United Nations Environmental Programme. (2002). Waste generation-how many million tons, really? Retrieved from http://www.vitalgraphics.net/waste/html_file/08-09_waste_generation.html.

Wilson, D. C. (2007). Development drivers for waste management. Waste Management and Research, 25, 198-207. http://dx.doi.org/10.1177/0734242X07079149

\section{Copyrights}

Copyright for this article is retained by the author(s), with first publication rights granted to the journal.

This is an open-access article distributed under the terms and conditions of the Creative Commons Attribution license (http://creativecommons.org/licenses/by/3.0/). 